\title{
ЯГОДНЫЕ КУСТАРНИКИ В ЛАНДШАФТНОЙ АРХИТЕКТУРЕ ГОРОДСКИХ МЕГАПОЛИСОВ
}

\author{
O.E. Khanbabaeva, I.V. Beryozkina, \\ V.N. Sorokopudov, O.A. Sorokopudova
}

\section{BERRY BUSHES IN THE LANDSCAPE ARCHITECTURE OF URBAN MEGACITIES}

\begin{abstract}
Ханбабаева Ольга Евгеньевна - канд. с.-Х. наук, доц. каф. ландшафртной архитектуры Российского государственного аграрного университета - МСХА им. К.А. Тимирязева, г. Москва E-mail: hanbabaeva@yandex.ru
\end{abstract}

Березкина Ирина Валентиновна - канд. с.-х. наук, доц. каф. ландшафтной архитектуры Российского государственного аграрного университета - МСХА им. К.А. Тимирязева, г. Москва, hanbabaeva@yandex.ru

Сорокопудов Владимир Николаевич - д-р с.-х. наук, проф. каф. декоративного садоводства и газоноведения Российского государственного аграрного университета - МСХА им. К.А. Тимирязева, г. Москва. E-mail: sorokopud2301@mail.ru

Сорокопудова Ольга Анатольевна - д-р биол. наук, проф. каф. ботаники, селекции и семеноводства садовых растений Российского государственного аграрного университета - МСХА им. К.А. Тимирязева, г. Москва.

E-mail: o.sorokopudova@rgau-msha.ru

B статье рассматриваются вопросы подбора ассортимента ягодных кустарников для озеленения городских ландшафртных объектов. Совместно с традиционными и популярными в частных садах ягодными культурами предложены малораспространенные виды и декоративные формы. Цель исследований расширение ассортимента декоративных кустарников в озеленении крупных мегаполисов и популяризация знаний о новых или малоизвестных видах ягодных кустарников. По значению коэфффициента адаптации исследуемые виды кустарников были разделены по степени перспективности на три группы. Наиболее перспективной группой, состоящей из $65 \%$ образцов, оказалась первая, представители которой характеризовались высокой зимостойкостью и способностью к полноценному семенному размножению, декоративностью. Среднеперспективная вторая групnа
Khanbabaeva Olga Evgenyevna - Cand. Agr. Sci., Assoc. Prof., Chair of Landscape Architecture, Russian State Agrarian University - MAA named after K. A. Timiryazev, Moscow. E-mail: hanbabaeva@yandex.ru

Berezkina Irina Valentinovna - Cand. Agr. Sci., Assoc. Prof., Chair of Landscape Architecture, Russian State Agrarian University - MAA named after K. A. Timiryazev, Moscow, hanbabaeva@yandex.ru

Sorokopudov Vladimir Nikolaevich - Dr. Agr. Sci., Prof., Chair of Decorative Gardening and Lawn Science, Russian State Agrarian University - MAA named after K. A. Timiryazev, Moscow.

E-mail: sorokopud2301@mail.ru

Sorokopudova Olga Anatolyevna - Dr. Biol. Sci., Prof., Chair of Botany, Selection and Seed Farming of Garden Plants, Russian State Agrarian University - MAA named after K. A. Timiryazev, Moscow.

E-mail: o.sorokopudova@rgau-msha.ru

включает 20 \% изучаемых образцов. Сюда вошли растения, которые в течение вегетации сохраняют декоративность, способные к размножению семенами, но они менее перспективны, чем представители 1-й группы, ввиду невозможности сохранять декоративность в условиях вегетационного периода и давать потомство самосевом. Третья - неперспективная группа, включала 15 \% образцов. Виды кустарников, относящиеся к данной группе, достаточно зимостойки, имеют способность $\kappa$ семенному размножению, но оказались не перспективными ввиду высоких требований к почвенным условиям произрастания и невысоких декоративных качеств в условиях мегаполиса. При использовании перечисленных видов растений для городского озеленения нужно соблюдать соответствующие нормативы для озеленения общественных пространств, скверов, бульваров, садов и парков. 
Ключевые слова: ландшафртная архитектура, ягодные кустарники, сорт, городское озеленение, декоративные формы, направления использования, тип посадки, ландшафотная организация насаждений.

The study deals with the selection of the assortment of berry bushes for landscaping urban landscape objects. Along with traditional and popular berry crops in private gardens not widespread types and decorative forms are offered. The purpose of the research is to expand the range of ornamental shrubs in the landscaping of large metropolitan areas and to popularize the knowledge about new or not famous types of berry bushes. Using the value of the adaptation coefficient the studied shrub species were divided into three groups according to the degree of prospects. The most promising group consisting of $65 \%$ of the samples was the first group, which representatives were characterized by high winter hardiness and the ability to complete seed propagation, decorative features. The average prospective second group includes $20 \%$ of the studied samples. It includes the plants retaining decorative features during vegetation, propagated by seeds, but less promising than the representatives of the 1-st group, due to the inability to maintain decorativeness in vegetation season and not giving offspring by selfseeding. The third group, which was not promising, included $15 \%$ of the samples. The species of shrubs belonging to this group are quite hardy, have the ability to seed propagation, but were not promising due to high requirements for soil conditions of growth and not high decorative qualities in a megalopolis. When using these types of plants for urban landscaping, one must comply with the relevant regulations for landscaping public spaces, squares, boulevards, gardens and parks.

Keywords: landscape architecture, berry bushes, variety, urban gardening, decorative forms, directions of use, type of planting, landscape organization of plantings.

Введение. На сегодняшний день одной из приоритетных градостроительных задач является обеспечение гармоничного развития человека в условиях городской среды с ее высокими антропогенными нагрузками. Решение этой задачи невозможно без увеличения нормы зеле- ных насаждений, приходящихся на одного жителя мегаполисов [1, 2].

В качестве основного элемента природной среды в городе выступают не только деревья, но и кустарники. Декоративные деревья и кустарники являются привычными для городского озеленения, а вот ягодные кустарники пока еще мало распространены [3-5].

В последние годы ягодные кустарники применяют для озеленения городов с декоративной целью, для расширения ассортимента. Ягодные кустарники имеют большое видовое разнообразие и уж тем более огромное разнообразие сортов, которые можно применить в ландшасртном озеленении. Достоинствами такого вида озеленения являются эстетичность, экологичность и экономичность, а также познавательная цель - ознакомление населения с существующими видами и сортами и особенно новинками селекции [6-12].

Цель исследований. Расширение ассортимента декоративных кустарников в озеленении крупных мегаполисов и популяризация знаний о новых или малоизвестных видах ягодных кустарников.

Методы исследований. Положительный успех интродукции зависит в первую очередь от степени адаптации интродуцентов к новым экологическим условиям [7, 13].

Для выявления адаптивности у видов декоративных кустарников к экологическим условиям мегаполисов нами был применен метод интегральной оценки [2, 4, 13-17]. В основу оценки положено семь биоэкологических показателей: зимостойкость, сохранение габитуса, побегообразовательная способность, регулярность прироста побегов, способность к генеративному развитию, возможность искусственного вегетативного размножения, а также декоративность $[6,9,13$, 15]. Данные показатели характеризуют состояние растения в месте интродукции и определяются путем систематических визуальных наблюдений. Для каждого показателя были подобраны числовые значения в баллах, соответствующие определенному состоянию растения. На основании проведенной интегральной оценки рассчитывался суммарный балл жизнеспособности кустарников отдельно по каждому году наблюдений и средний балл за период наблюдений. Интегральным числовым выражением жизнеспособности интродуцированных растений является сумма средних баллов $[1,9,13,16]$. 
Результаты исследований и их обсуждение. На основании собственных исследований [5, 9-13] за время работы с ягодными культурами с 1990 года и изучения литературных источников по вопросам озеленения населенных мест в городах и селах России составлена таблица (табл. 1) по использованию и декоративной ценности различных видов ягодных и плодовых растений в условиях населенных мест. В таблице 1 представлены основные виды, сорта и декоративные формы ягодных кустарников, которые можно использовать в качестве озеленения городских садов и парков. Особенностью этих культур является высокая декоративность, неприхотливость и адаптивность к городским условиям, без потери своих декоративных качеств $[1,9,10]$.

У многих декоративных видов кустарников в период наблюдений нами практически не зафиксировано наличие повреждений от низких температур, их побеги к концу периода вегетации одревесневают на 90-100 \%, и только в суровые зимы наблюдается отмирание концов у поздновегетирующих побегов. Данное подмерзание верхушек однолетних приростов вызвано неустойчивыми зимами с резкими колебаниями температур и оттепелями, которые наблюдались в годы проводимых исследований. Однако представленные декоративные виды кустарников легко восстанавливают надземную часть, ежегодно цветут и плодоносят.

Таким образом, в условиях интродукции в Москве и области кустарники являются устойчивыми, побеги их не обмерзают в зимний период и почти полностью одревесневают к концу вегетационного периода.

При интродукции в условиях мегаполиса г. Москвы жизненная форма изучаемых растений сохраняется такой же, в какой они произрастали в естественном ареале, - кустарники [1, 3-5, 9]. После воздействия негативных фракторов среды побегообразовательная способность растений обуславливает сохранение или восстановление габитуса кроны. Проведенные исследования показали, что все исследуемые нами виды характеризуются высокой побегообразовательной способностью [10-12].

Важнейшим показателем жизнедеятельности растения является его рост. Прирост побегов обобщающий комплексный показатель, синте- зирующий не только результаты жизнедеятельности организма растения, но и аккумулирующий в себе комплексное влияние на растения окружающей среды обитания. Развитие и рост кустарников являются наиболее важными показателями приспособления растений при интродукции в новые географиические районы [2, 13, 15-17]. Проведенные наблюдения показали, что у всех изучаемых образцов ежегодный прирост побегов составлял от 9 см до 1,3 м, что было обусловлено потенциальной скоростью роста кустарников.

Выявляется успешность интродукции, как и их репродуктивная способность. Формирование у растений жизнеспособных фертильных семян говорит об их достаточной адаптированности к условиям среды в мегаполисе. Продуцирование жизнеспособных семян, определяющих развитие устойчивых семенных поколений, обеспечивает растениям выживание и распространение в новых условиях. Проведенные наблюдения в условиях г. Москвы выявили ежегодное плодоношение и образование жизнеспособныхе семян у всех исследуемых видов. В итоге по значению коэффициента адаптации исследуемые виды кустарников были разделены нами по степени перспективности на три группы. Наиболее перспективной группой, состоящей из $65 \%$ образцов, оказалась первая, представители которой характеризовались высокой зимостойкостью и способностью к полноценному семенному размножению, декоративностью.

Среднеперспективная вторая группа включает $20 \%$ изучаемых образцов. Сюда вошли растения, которые в течение вегетации сохраняют декоративность, способны к размножению семенами, но они менее перспективны, чем представители 1-й группы, ввиду невозможности сохранять декоративность в условиях вегетационного периода и давать потомство самосевом.

Третья - неперспективная группа включала 15 \% образцов. Виды кустарников, относящиеся к данной группе, достаточно зимостойки, имеют способность к семенному размножению, но оказались неперспективными ввиду высоких требований к почвенным условиям произрастания и невысоких декоративных качеств в условиях мегаполиса. 


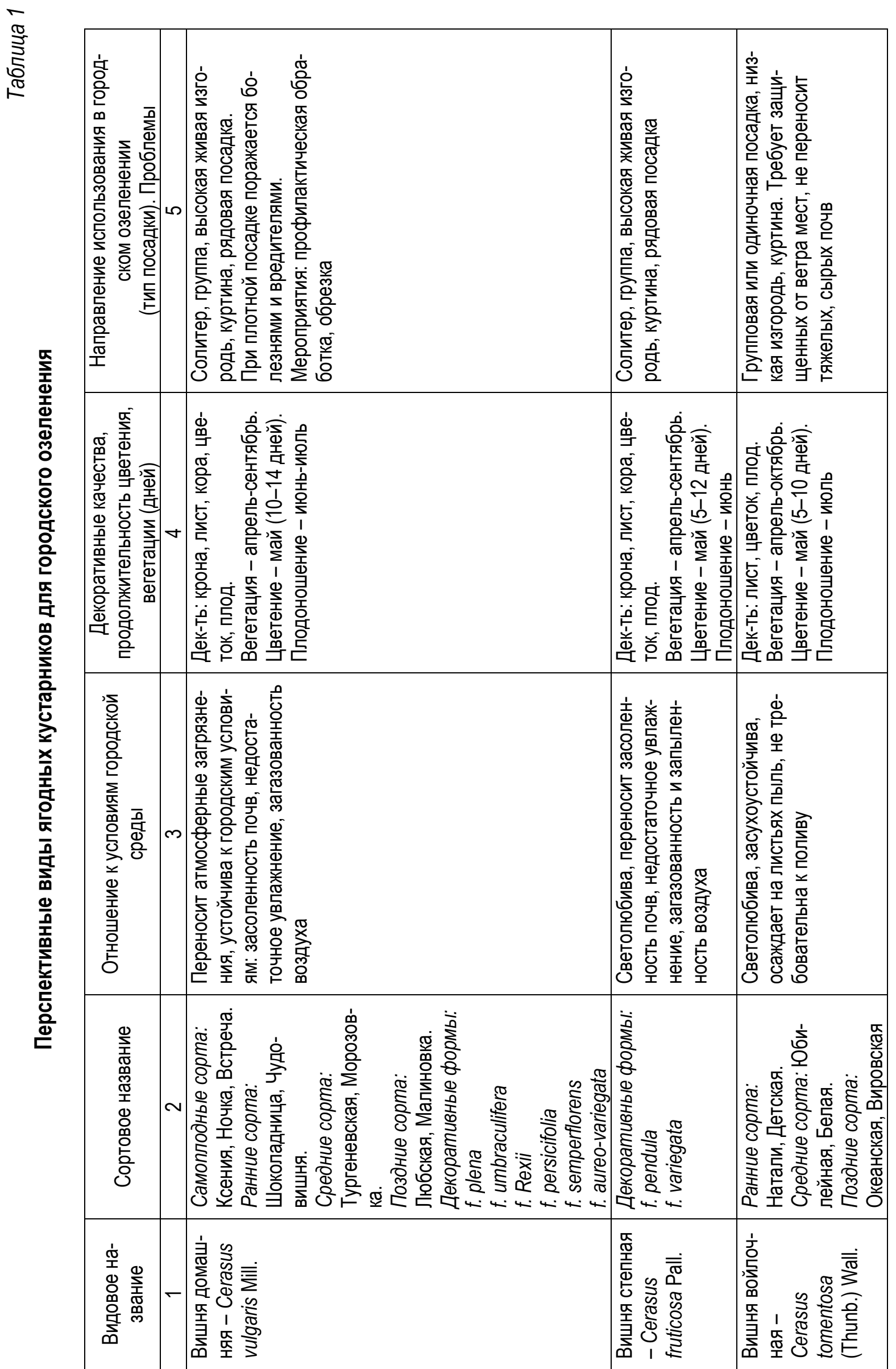




\begin{tabular}{|c|c|c|c|c|c|c|}
\hline & 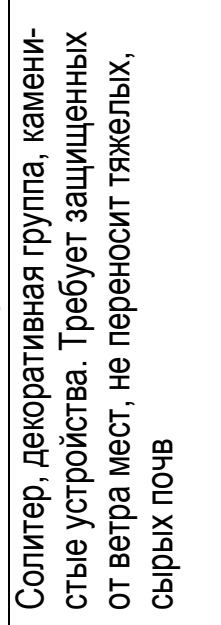 & 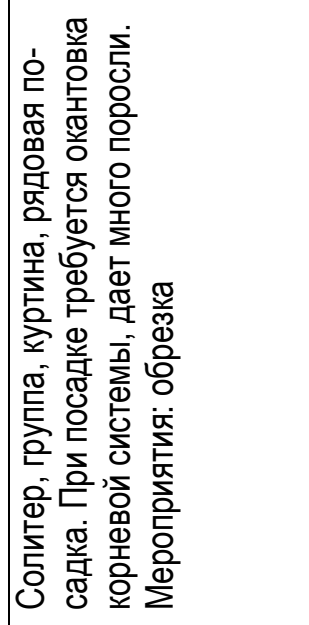 & 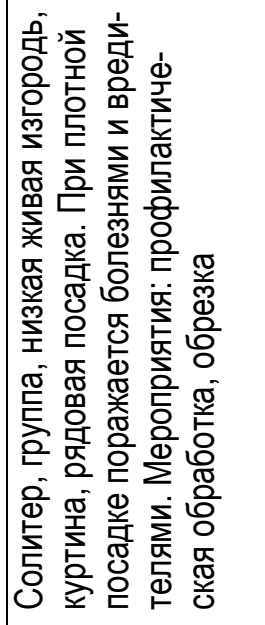 & 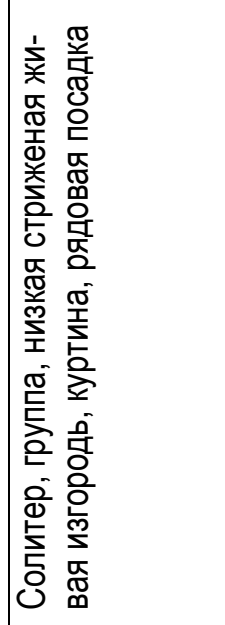 & 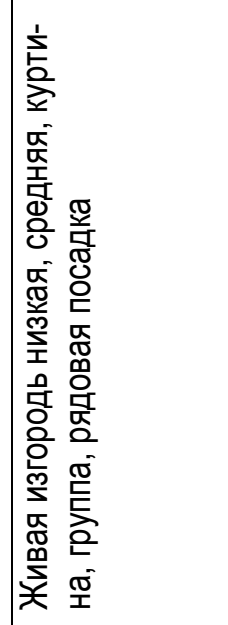 & 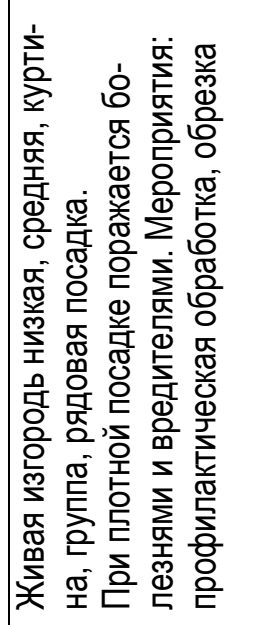 \\
\hline$\nabla$ & 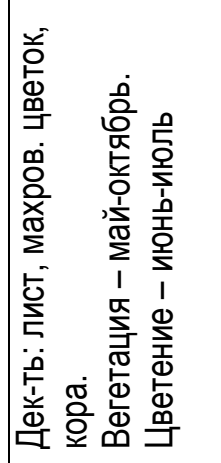 & 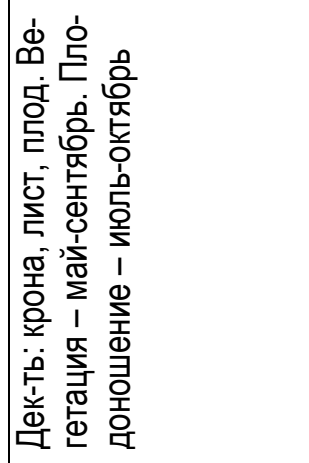 & 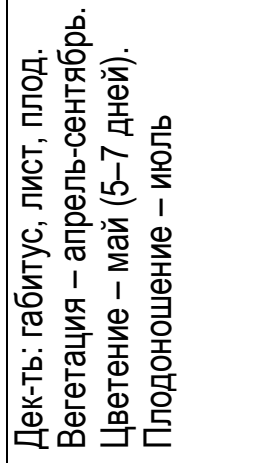 & 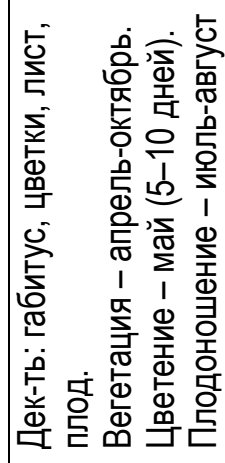 & 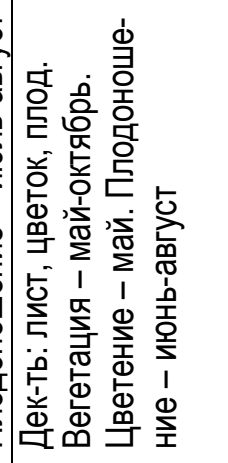 & 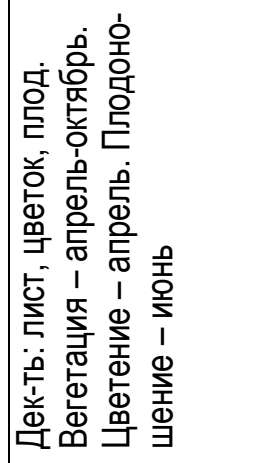 \\
\hline$m$ & 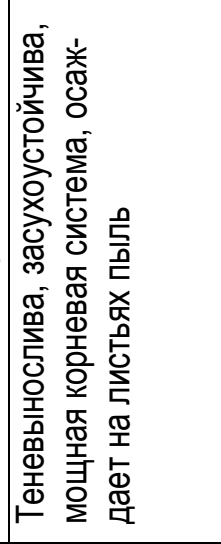 & 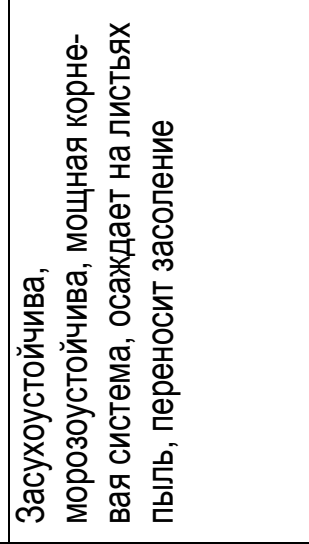 & 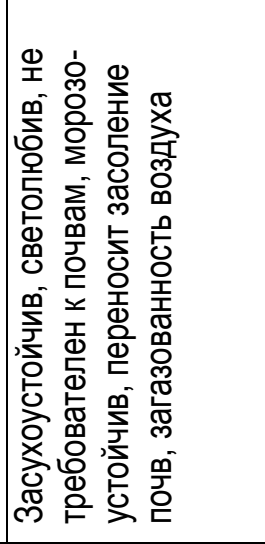 & 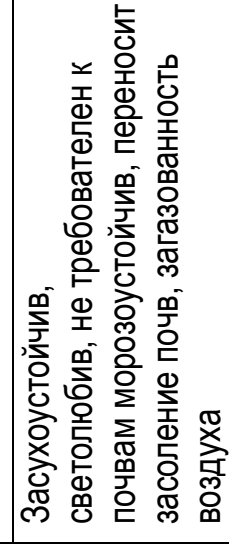 & 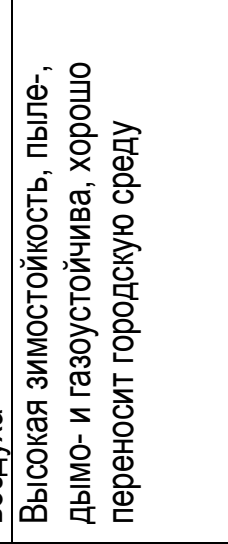 & 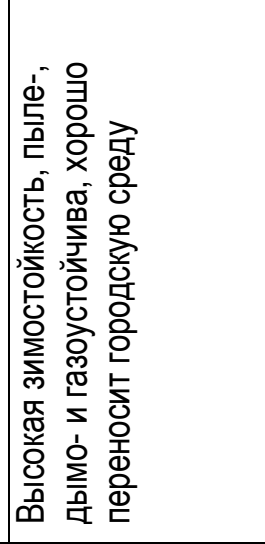 \\
\hline$\sim$ & 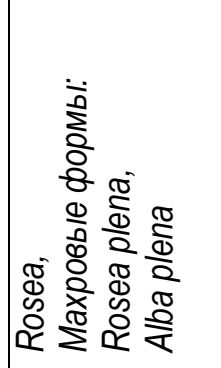 & 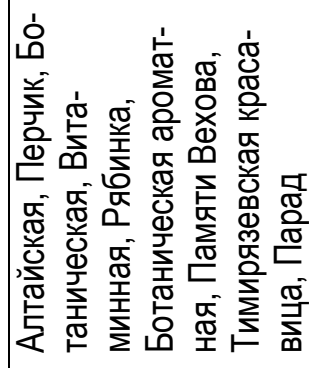 & 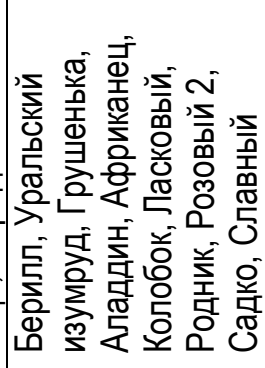 & 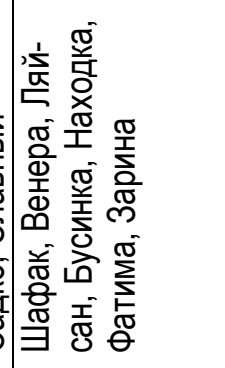 & 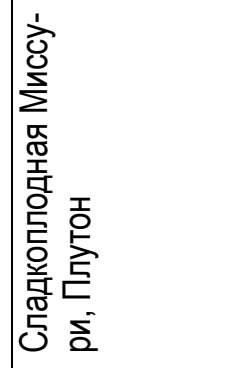 & 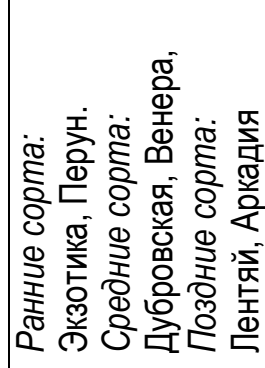 \\
\hline & 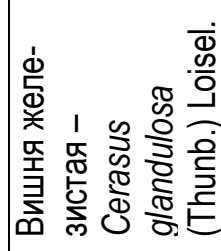 & 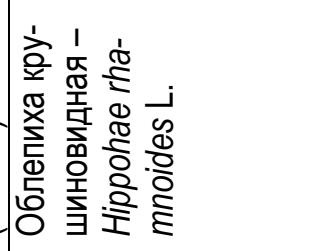 & 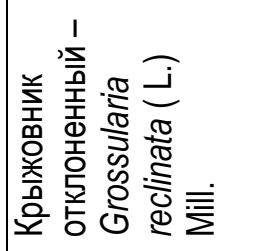 & 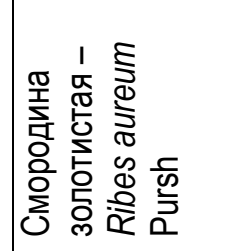 & 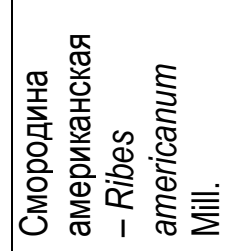 & 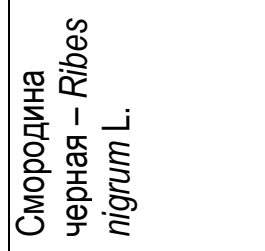 \\
\hline
\end{tabular}




\begin{tabular}{|c|c|c|c|c|c|}
\hline & 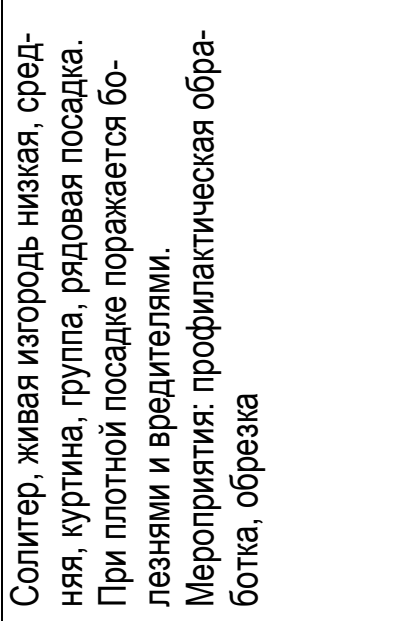 & 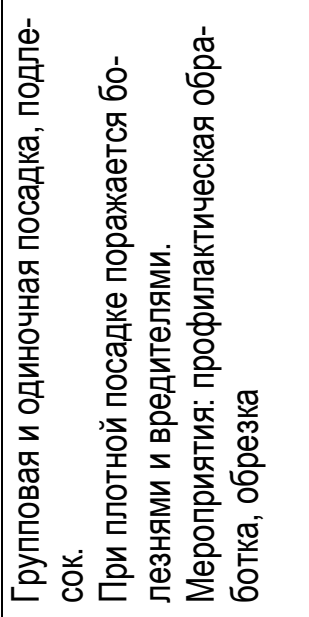 & 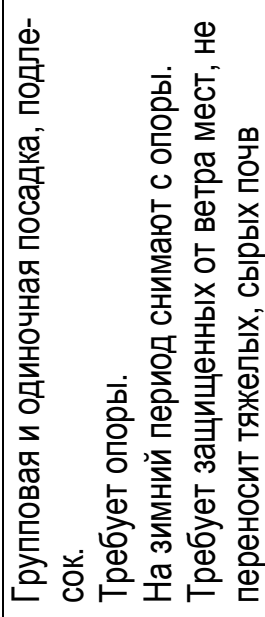 & 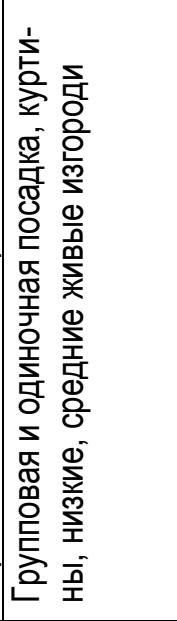 & 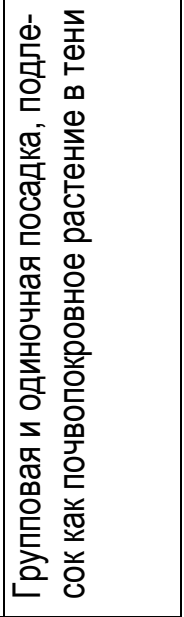 \\
\hline$\nabla$ & 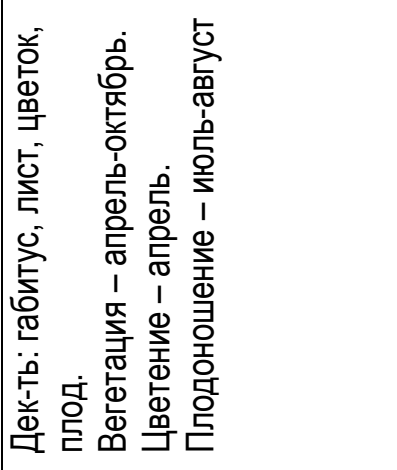 & 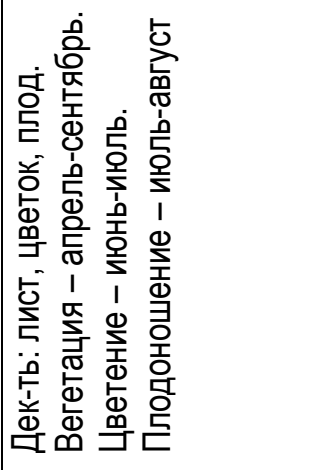 & 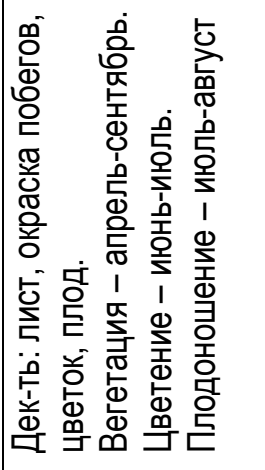 & 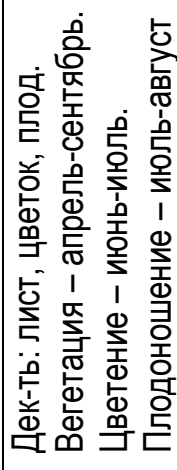 & 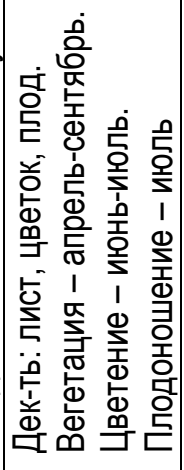 \\
\hline m & 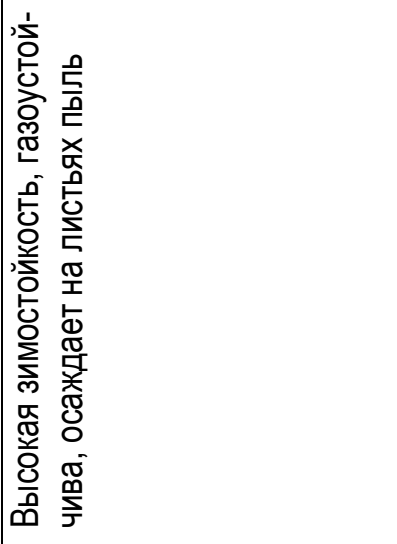 & 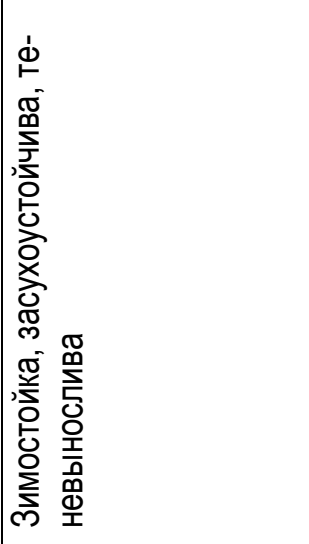 & 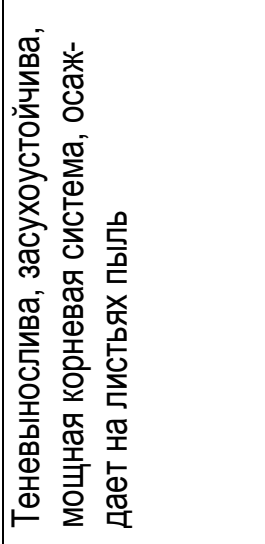 & 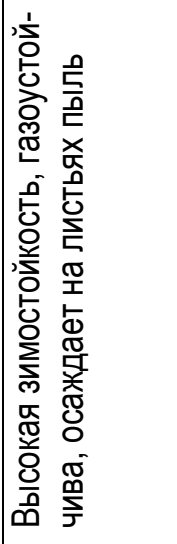 & 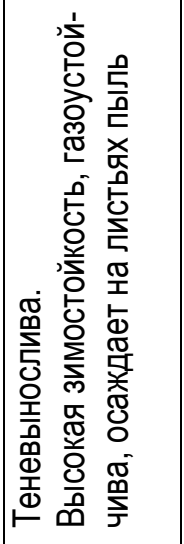 \\
\hline$\sim$ & 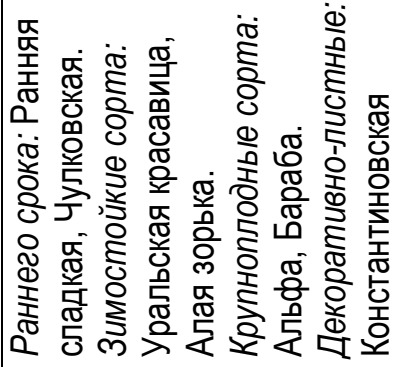 & 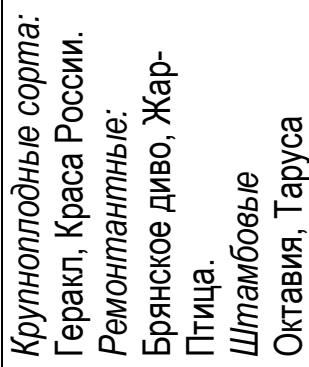 & 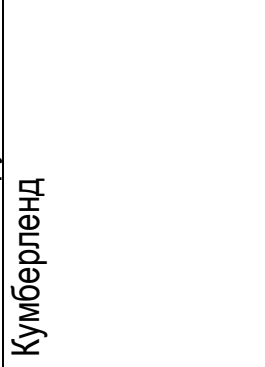 & 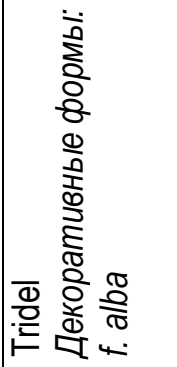 & 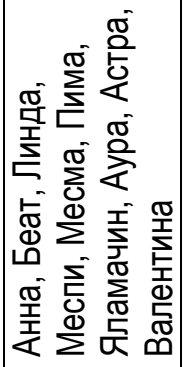 \\
\hline & 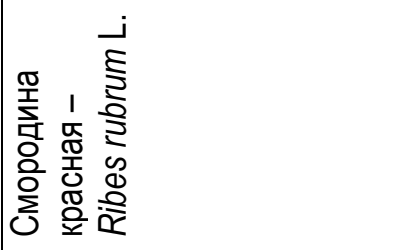 & 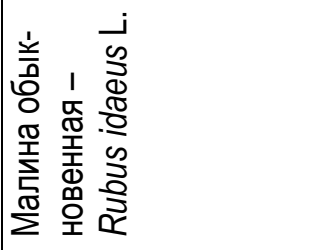 & 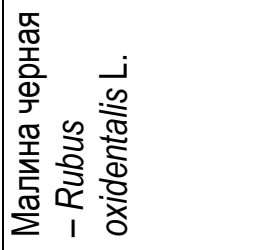 & 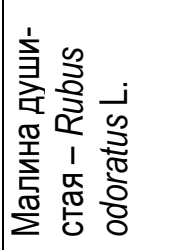 & 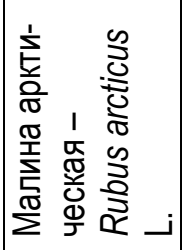 \\
\hline
\end{tabular}




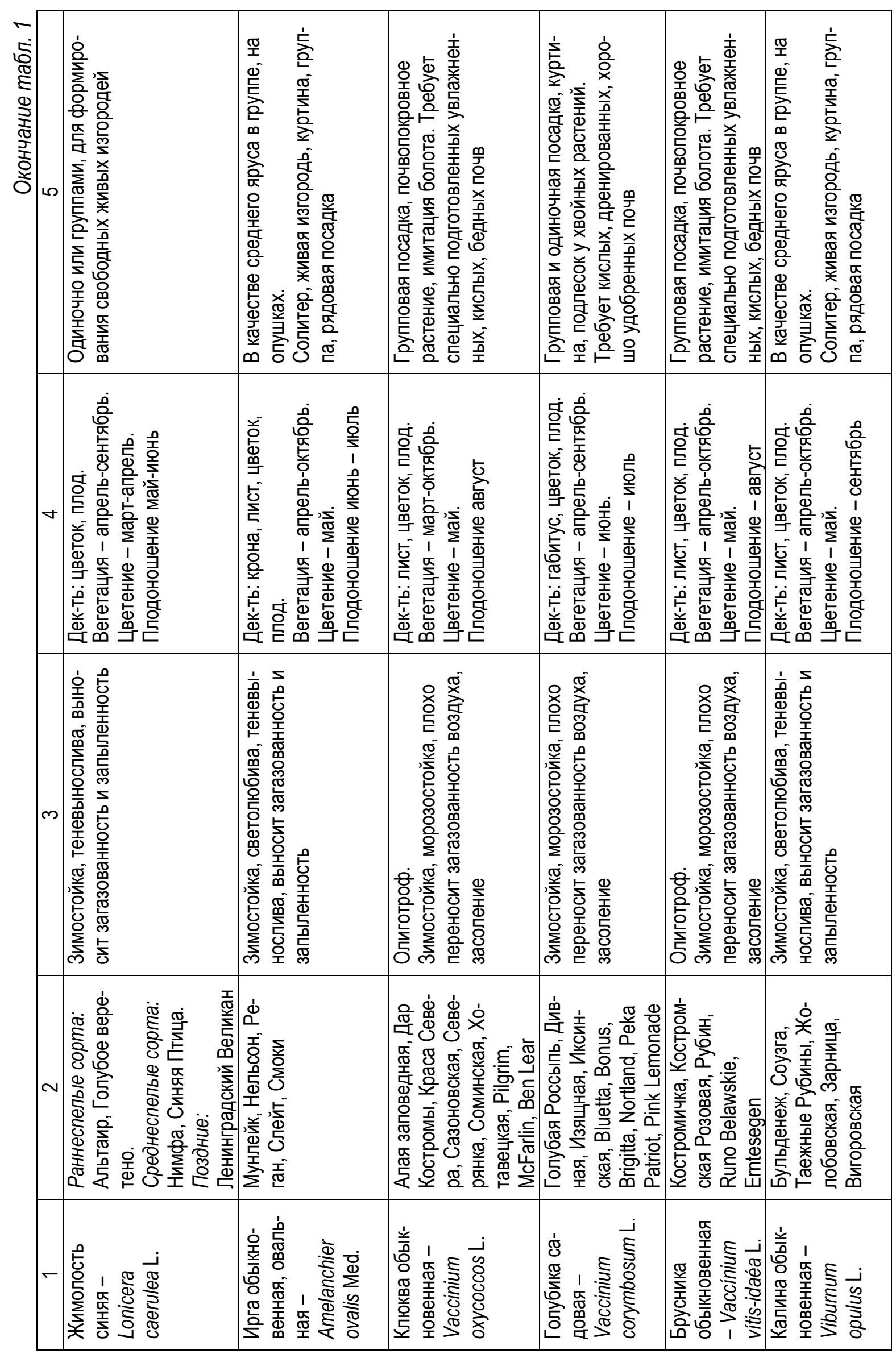




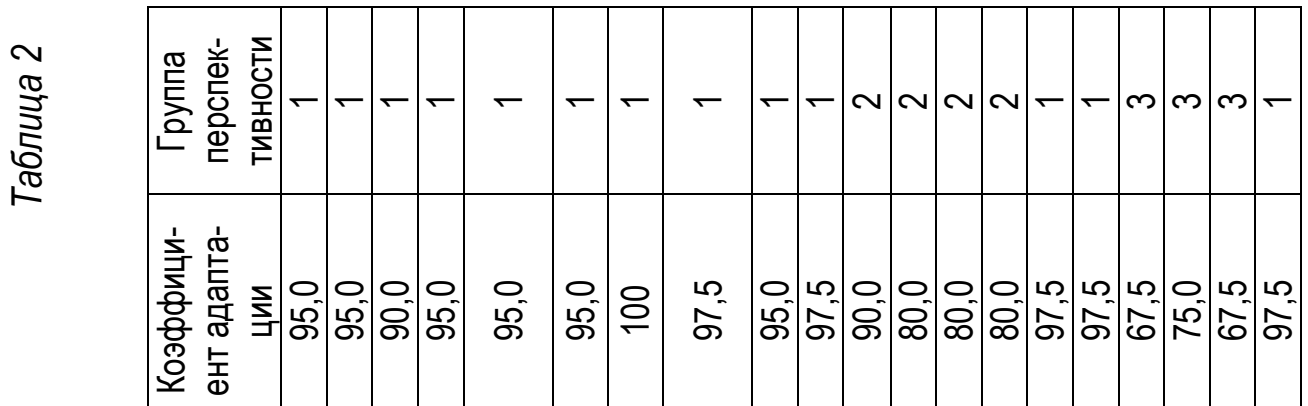

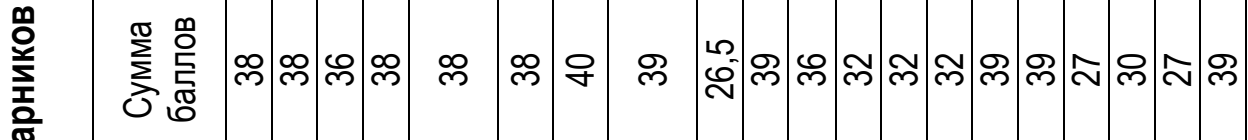

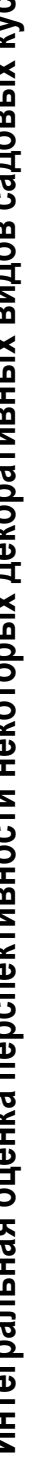

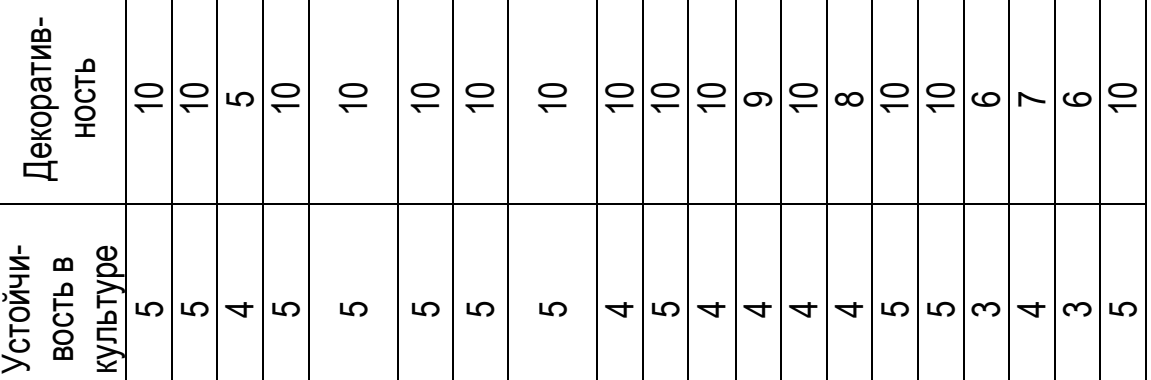
空 商

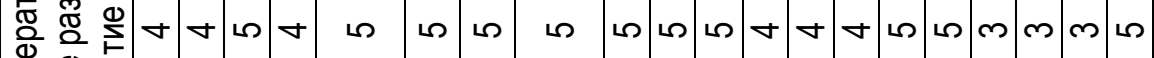
폰 오

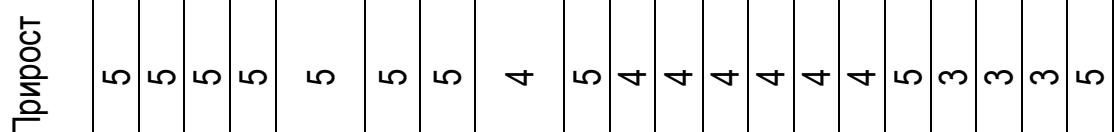

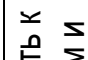

点 $\sum_{\text {依 }}^{\infty}$

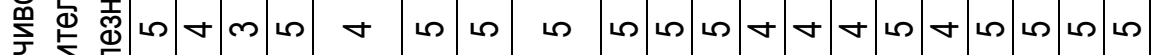
흔 항

$>$ 용

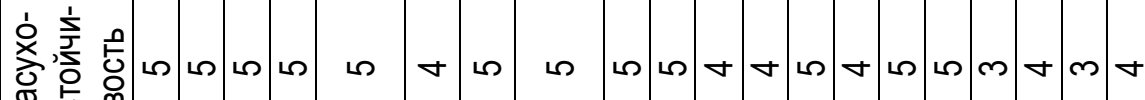
峁

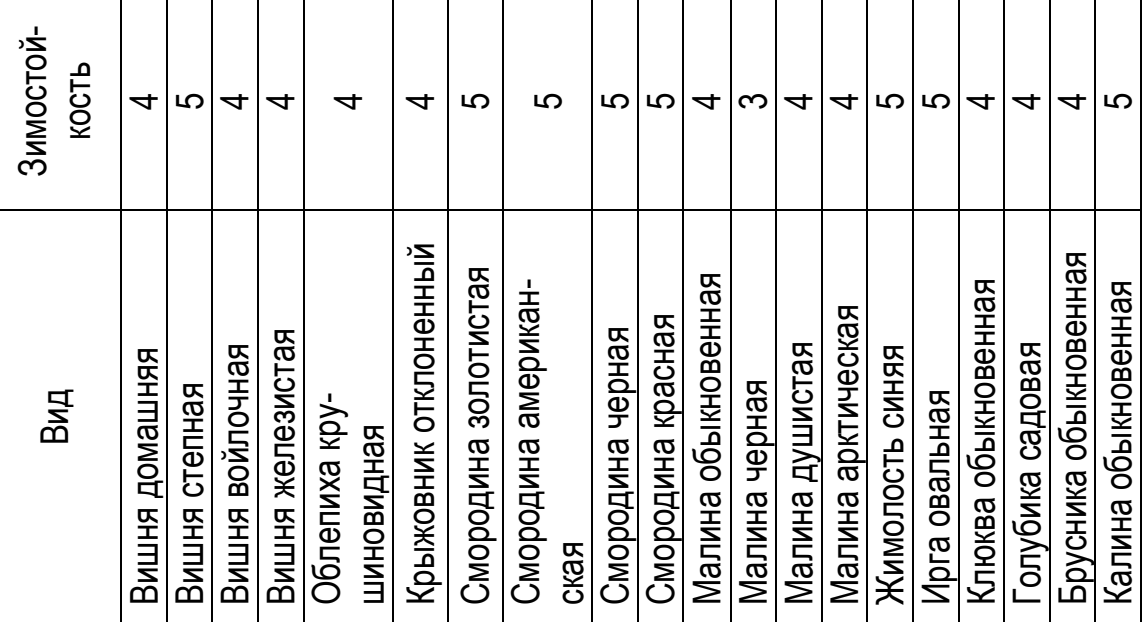


При использовании перечисленных видов растений для городского озеленения нужно соблюдать соответствующие нормативы для озеленения общественных пространств, скверов, бульваров, садов и парков. В частности, недопустимо применять околюченные виды с ядовитыми листьями, цветками и плодами, а также растения, которые сильно поражаются болезнями и повреждаются вредителями.

В представленном сортименте встречаются виды, содержащие шипы и колючки на побегах, например крыжовник, облепиха, малина, но сортимент подобран таким образом, что в него включены сорта, практически не имеющие колючек и шипов (см. табл. 1).

Практически все культуры не требуют специальной подготовки почвы для большинства культур, исключение составляют представители семейства Вересковые (клюква, брусника, голубика), требующие специальных бедных, рыхлых, кислых и увлажненных почв.

Большинство видов имеет декоративные цветки, соцветия и мелкие, яркие съедобные плоды. При небольших размерах и количестве плодов исключена порча покрытий, неприятный запах при опадении плодов и желание посетителей садов и парков употреблять их в свежем виде.

Для некоторых культур, популярных плодовых или ягодных (вишня, смородина, малина), характерно частое повреждение вредителями и болезнями при отсутствии должного ухода. Но отказываться от них для целей городского озеленения не стоит, так как они придают озеленяемым ландшафртам особую привлекательность и несут важный практический смыл - популяризация знаний о подобных культурах у населения. Для поддержания декоративности у подобных растений необходимо проводить регулярную обрезку, формировку, профилактические обработки и агротехнические приемы.

Таким образом, представленный ассортимент кустарников является перспективным для городского озеленения. Применение перечисленных культур расширит традиционный ассортимент кустарников для городского озеленения, совместно с декоративными деревьями они создадут высокодекоративные посадки. При соответствующем уходе и уровне агротехники рекомендуемые виды будут выглядеть декоративно, при этом также выполнять важную информационно-обучающую функцию.

\section{Выводы}

1. Исследуемые виды кустарников разделены по значению коэфффициента адаптации, степени перспективности на три группы.

2. Наиболее перспективна группа первая $65 \%$ видов (вишня домашняя, степная, войлочная и железистая, облепиха крушиновидная, крыжовник отклоненный, смородина золотистая, американская, черная и красная, малина обыкновенная), представители которой характеризуются высокой зимостойкостью и способностью к полноценному семенному и вегетативному размножению, декоративностью.

3. Среднеперспективная вторая группа включает 20 \% изучаемых видов (малина черная, малина душистая, малина арктическая).

4. Третья - неперспективная группа включает $15 \%$ образцов (клюква обыкновенная, голубика топяная, брусника обыкновенная), которые не перспективны ввиду высоких требований к почвенным условиям произрастания и невысоких декоративных качеств в условиях мегаполиса.

\section{Литература}

1. Иванова И.В., Ханбабаева О.Е. Каменистый сад: учеб. пособие. М., 2012. 123 с.

2. Колесников А.И. Декоративная дендрология. М.: Лесная промышленность, 1974. 704 с.

3. Иванова И.В., Пономарева Ю.Г., Ханбабаева O.E. Декоративное садоводство: учеб. пособие. М., 2014. 146 с.

4. Ханбабаева О.Е. Декоративная дендрология. Покрытосеменные растения: мультимед. учеб. пособие. Свидетельство о регистрации базы данных RU 2013620649. Заявка № 2013620365 от 17.04.2013.

5. Ханбабаева O.Е. Декоративные древесные культуры в дизайне сада: монография. М.: Изд-во МЭСХ, 2018. 132 с.

6. Ковалева И.С., Мацнева А.Е., Ханбабаева O.E. [и др.]. Введение в культуру in vitro и клональное микроразмножение перспективного сеянца смородины черной (Ribes nigrum L.) // Вестник КрасГАУ. 2019. № 12 (153). C. 43-48. DOI: 10.36718/1819-40362019-12-43.

7. Селехов А.Н., Ханбабаева О.Е. Комплексная оценка цветочного оформления города Москвы // Вестник ландшафттнй архитектуры. 2014. № 4. С. 67-71. 
8. Селехов А.Н., Ханбабаева О.Е. Оптимизация методики анкетирования М.Ю. Фроловой для анализа предпочтений в цветочном оформлении городских парков Москвы // Вестник ландшафтной архитектуры. 2015. № 5. C. 72-77.

9. Сорокопудов В.Н., Мартынова Н.А., Ширина Л.С. [и др.]. Интегральная оценка перспективности новых сортов жимолости альпийской в условиях Белгорода // Субтропическое и декоративное садоводство. 2015. № 55. C. 73-78.

10. Бурменко Ю.В., Сорокопудов В.Н., Шлапакова С.Н. [и др.]. Возможности использования смородины золотистой (Ribes aureum Pursh) в качестве объекта ландшафтнопаркового строительства // Вестник Хакасского государственного университета им. Н.Ф. Катанова. 2015. № 13. С. 50-51.

11. Сорокопудов В.Н., Бурменко Ю.В., Нuематзянов Р.А. Перспективы селекции смородины золотистой // Вестник Хакасского государственного университета им. Н.Ф. Катанова. 2015. № 13. С. 93-95.

12. Сорокопудов В.Н., Куклина А.Г., Шлапакова С.Н. Декоративные виды жимолости для озеленения населенных пунктов // Вестник Хакасского государственного университета им. Н.Ф. Катанова. 2015. № 13. С. 95-97.

13. Арестова E.A. Интегральная оценка перспективности растений рода Sorbus L. B дендрарии НИИСХ юго-востока // Лесное хозяйство Поволжья. Саратов, 2002. Вып. 5. С. 98-102.

14. Скакова А.Г., Ханбабаева О.Е. Проектирование специализированных объектов ландшафтной архитектуры: учеб.-метод. пособие. М., 2018. 124 с.

15. Карпун Ю.Н. Основы интродукции растений // Сохранение и мобилизация генетических ресурсов в ботанических садах. Сочи, 2004. Вып. 2. С. 17-32.

16. Лапин, П.И., Рябова-Стогова Н.В. Оценка перспективности интродукции жимолости по данным визуальных наблюдений // Бюл. ГБС. М.: Наука, 1977. Вып. 103. С. 12-18.

17. Плотникова Л.С. Научные основы интродукции и охраны древесной растительности фрлоры СССР. М.: Наука, 1988. 264 с.

\section{Literatura}

1. Ivanova I.V., Hanbabaeva O.E. Kamenistyj sad: ucheb. posobie. M., 2012. $123 \mathrm{~s}$.

2. Kolesnikov A.I. Dekorativnaja dendrologija. M.: Lesnaja promyshlennost', 1974. $704 \mathrm{~s}$.

3. Ivanova I.V., Ponomareva Ju.G., Hanbabaeva O.E. Dekorativnoe sadovodstvo: ucheb. posobie. M., 2014. $146 \mathrm{~s}$.

4. Hanbabaeva O.E. Dekorativnaja dendrologija. Pokrytosemennye rastenija: mul'timed. ucheb. posobie. Svidetel'stvo o registracii bazy dannyh RU 2013620649. Zajavka № 2013620365 ot 17.04 .2013 .

5. Hanbabaeva O.E. Dekorativnye drevesnye kul'tury v dizajne sada: monografija. M.: Izd-vo MJeSH, 2018. $132 \mathrm{~s}$.

6. Kovaleva I.S., Macneva A.E., Hanbabaeva O.E. [i dr.]. Vvedenie $v$ kul'turu in vitro $\mathrm{i}$ klonal'noe mikrorazmnozhenie perspektivnogo sejanca smorodiny chernoj (Ribes nigrum L.) // Vestnik KrasGAU. 2019. № 12 (153). S. 4348. DOI: 10.36718/1819-4036-2019-12-43.

7. Selehov A.N., Hanbabaeva O.E. Kompleksnaja ocenka cvetochnogo oformlenija goroda Moskvy // Vestnik landshaftnoj arhitektury. 2014. № 4. S. 67-71.

8. Selehov A.N., Hanbabaeva O.E. Optimizacija metodiki anketirovanija M.Ju. Frolovoj dlja analiza predpochtenij $v$ cvetochnom oformlenii gorodskih parkov Moskvy // Vestnik landshaftnoj arhitektury. 2015. № 5. S. 72-77.

9. Sorokopudov V.N., Martynova N.A., Shirina L.S. [i dr.]. Integral'naja ocenka perspektivnosti novyh sortov zhimolosti al'pijskoj v uslovijah Belgoroda // Subtropicheskoe i dekorativnoe sadovodstvo. 2015. № 55. S. 73-78.

10. Burmenko Ju.V., Sorokopudov V.N., Shlapakova S.N. [i $\quad$ dr.]. Vozmozhnosti ispol'zovanija smorodiny zolotistoj (Ribes aureum Pursh) $v$ kachestve ob'ekta landshaftno-parkovogo stroitel'stva // Vestnik Hakasskogo gosudarstvennogo universiteta im. N.F. Katanova. 2015. № 13. S. 50-51.

11. Sorokopudov V.N., Burmenko Ju.V., Nigmatzjanov R.A. Perspektivy selekcii smorodiny zolotistoj // Vestnik Hakasskogo gosudarstvennogo universiteta im. N.F. Katanova. 2015. № 13. S. 93-95. 
12. Sorokopudov V.N., Kuklina A.G., Shlapakova S.N. Dekorativnye vidy zhimolosti dlja ozelenenija naselennyh punktov // Vestnik Hakasskogo gosudarstvennogo universiteta im. N.F. Katanova. 2015. № 13. S. 95-97.

13. Arestova E.A. Integral'naja ocenka perspektivnosti rastenij roda Sorbus L. V dendrarii NIISH jugo-vostoka /I Lesnoe hozjajstvo Povolzh'ja. Saratov, 2002. Vyp. 5. S. 98-102.

14. Skakova A.G., Hanbabaeva O.E. Proektirovanie specializirovannyh ob\#ektov landshaftnoj arhitektury: ucheb.-metod. posobie. M., 2018. $124 \mathrm{~s}$.

15. Karpun Ju.N. Osnovy introdukcii rastenij // Sohranenie i mobilizacija geneticheskih resursov v botanicheskih sadah. Sochi, 2004. Vyp. 2. S. 17-32.

16. Lapin, P.I., Rjabova-Stogova N.V. Ocenka perspektivnosti introdukcii zhimolosti po dannym vizual'nyh nabljudenij // Bjul. GBS. M.: Nauka, 1977. Vyp. 103. S. 12-18.

17. Plotnikova L.S. Nauchnye osnovy introdukcii i ohrany drevesnoj rastitel'nosti flory SSSR. M.: Nauka, 1988. $264 \mathrm{~s}$. 